\title{
Myth in Plato's philosophy
}

\section{Luiz Maurício Bentim da Rocha Menezes ${ }^{1}$}

\begin{abstract}
1 Doutor em Filosofia (UFRJ). Professor de Filosofia, Ética e Política do Instituto Federal de Educação, Ciência e Tecnologia do Triângulo Mineiro E-mail: Imbrmenezes@yahoo.com.br. Orcid: http://orcid.org/0000-0003-4925-9876
\end{abstract}

ABSTRACT: The aim of this paper is the analysis of myth in Plato's work based on a paper of Ludwig Edelstein. In his work, Edelstein presents to us the reason why Plato uses myth and its function in his philosophy. The author contributes to the development of thought on the subject and provides development for later studies on myth in Plato. We finished with a critical conclusion about the relation of dialectics and myth.

Keywords: Plato. Myth. Edelstein. Ancient Philosophy.

This work aims to study the function that myth plays in Platonic philosophy from studies of Edelstein. Although dialectic is central to Plato, he is also an adept of myth and has in this an important function for his philosophy. Myth, in general, has the power of enchantment over its listeners and the author will question what role of myth for philosophy is, since the role of enchanting and captivating through it is originally from poetry. Philosophers before Plato had dismissed myth as worthless, and even sophists and thinkers of the time sought to find a hidden meaning [ jóvoı ] behind the myth that could lead to their true interpretation ${ }^{1}$. Investigating the motive that leads Plato to retake myth as a way of thinking philosophy is something we intend to investigate.

Before raising his own hypotheses in this regard, Edelstein will demonstrate how later he saw Plato's use of his myths. For Hegel, the Platonic myths are appropriate only for the childhood of humanity, when reason is still being born, after which they become obsolete. Neo-Platonic and Neo-Kantian will present opposing views. For the former, Plato's myths are allegorical and there is in them true philosophical meaning. For the latter, reason has limits, and problems of the soul and the cosmos can only be discussed through images; myths of Plato are an instrument by which transcendental feeling is awakened and regulated. As for Romanticism, Plato was not only aware of the limits of reason, he knew that myth was the inspiration that the philosopher shared with the poet, leading to the revelation of the truth of supra-rational of the divine (Edelstein, 1949, p. 463-464).

Divergent to these interpretations are all those which recognize the fact that the question of the meaning of Platonic myths is linked with the related problems between reason and imagination ${ }^{2}$ between philosophy and poetry. What for author puts two aspects to be analyzed: philosophical and aesthetic. For him, Platonic myth is not an entirely artificial creation, but a response against tradition to traditional Greek mythology. With this in view, Edelstein will begin his analysis by Plato's attitude to common beliefs.

According to him, at the time of Plato, mythology was still a living power founded on the traditional religion demonstrated mainly by Homer and Hesiod (Edelstein, 1949, p. 465) ${ }^{3}$. Plato considered such religion

\footnotetext{
1 More on the subject can be read in Tate (1929, p.143).

2 Veyne (1987, p.12), demonstrates the relevance of understanding the imagination so that the myth can be understood. He tells us in his Preface: "I do not want to say that the imagination would announce future truths and that it should be in power, but that truths are already imaginations and that imagination has been in power forever; it, and not reality, reason or the long work of the negative".

3 To affirm this, it will use the passage 379th of the Republic, where Plato speaks of the types [TúmoI] to be used when
} 
unholy and full of errors. In this way, mythology should be completely reformulated ${ }^{4}$, which causes Plato to

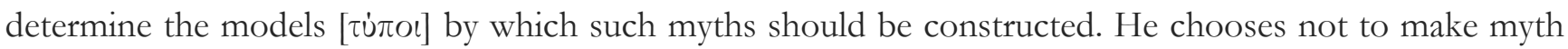
merely an allegorical interpretation because children are not able to distinguish what is from what is not allegorical. Myth must be made according to results of philosophy; stories must be told to children as a reflection of dialectical truth. In this way, mythology could be used properly in education (EDELSTEIN, 1949, page 465). A philosopher, Edelstein said, must be able to distinguish what is from an allegory, for

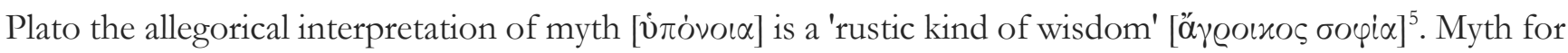
Plato is formed by will, it is not an antithesis of reason, that way mythos it functions as an instrument of the logos. For Edelstein, this means that myth does not possess certainty inherent in dialectic, and can only persuade (Edelstein, 1949, 466). But such persuasion is not for an inferior class of ordinary men and nonphilosophers, the philosopher must also believe in myth, for philosophical inquiry needs myth (Edelstein, 1949, 466). That said, Edelstein will deny the previous three theses: myth as allegory (Neo-platonic) is false because Plato considers it a rustic wisdom; myth with a high knowledge (Kantian) is false, for reason is supreme in Plato, myth being subservient to it; and myth as a mystery to be revealed (Romanticists), for to Plato, myth is myth of the philosopher (Edelstein, 1949, p 467).

Denied the above theses, Edelstein will classify myths into two groups:

I) Those who report the creation of the world and the principle of humanity.

II) Those who deal with destiny of soul before and afterlife without having to do with metaphysics, but with ethics.

Regarding the first group, he tells us, that human reason can only understand what is always and does not change. If one intends to speak of what changes, characteristic of the history of the world, one can only do this through an account of a myth. Not because it is self-consistent or exact, for what it presents is imagined probabilities rather than ascertaining facts. An investigation into the beginning of history is mythology (Edelstein, 1949, p 468) ${ }^{6}$. About what is false or true in such accounts is somewhat uncertain, for temporal events it is only possible to have standards of an eternal nature. "If taken as a symbol of eternity, the world is understood correctly" (Edelstein, 1949, p 468). Facts themselves will always be conjectures, which we can never be absolutely sure of the truth, for, as Edelstein tells us, "it is inherent in the nature of human understanding that truth and falsehood are forever closely interwoven" (Edelstein, 1949, p.469).

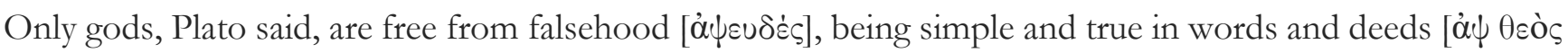

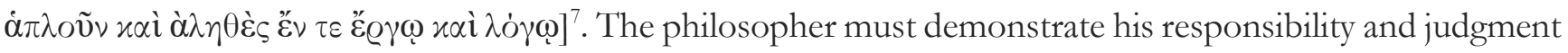
by not going beyond what his knowledge can take so that historical myths serve to clarify logical difficulties. Edelstein will attempt to explain this using Plato's premise that nothing in the world exists without its

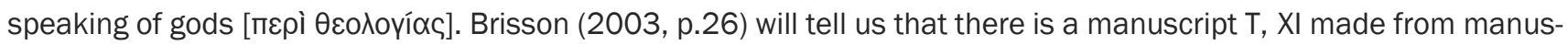

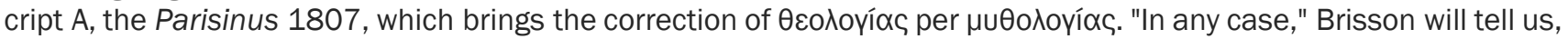
"although the correction is not accepted, it must be admitted that in this passage theologies are synonymous with mythologies".

4 In Euthyphro, 6a-c, Socrates says he does not think such reports about the gods are true.

5 Such passage is taken from an interpretation of the Phaedrus, 229b-230a.

6 On this we can say that until today this is done. All science about man's prehistory or its beginnings is still an "advanced mythology." In science fiction films, such as Stanley Kubrick's "2001: A Space Odyssey", such features are well explored.

7 Republic, 382e. Greek text established by John Burnet, Platonis Opera, Tomvs IV Oxford: Oxford University Press, 1902. Other citations to the 'Republic' will be abbreviated by Rep. 
opposite $^{8}$. For something to exist, the other must exist. In the case, the serious one has as an opposite joke. The written dialogues were composed carefully to capture the best, most convincing logos, so myths are compounded with infinite care, to make fable that relates most likely. Seriousness and playfulness are posed as a peculiar ambiguity of Platonic irony. They are two indissoluble aspects of human and perhaps of the divine (Edelstein, 1949, pp. 470-471).

Plato discusses with various thinkers of the day as the philosophers of nature and critical historians who have excluded the myth from their investigations. The most extreme would be Democritus who proposes a rational analysis of nature and Thucydides that separates history from mythology. The important point is that Plato thinks the reason of limitations where the old rationalism, as well as the modern rationalism, detects the force of reason is combined with the experience. However, Plato does not value this reason capable of proving the principles of an interpretation of natural and historical facts. For Plato, it is the task of reason and myth to influence where Kant's rational causality reigns supreme. The reason is able to provide principles of nature and history, even if such principles are given through myth. Thus, while the historical tale is a practical value, the philosophical myth is intellectual fun (EDELSTEIN, 1949, p. 472).

As for the second group, concerning soul problems, Edelstein tells us that Socrates through the thesis of the immortality of soul could refute anyone who tried to defend an amorality or injustice. To the author, the ethical case is different from natural and historical science, for human reason is able to account for its task, which is to provide knowledge. Ethical myth is an addition to rational knowledge; you do not want to replace it, but support it. Transcendence, he shows through pictures and images, follows a rigid standard of construction: that there is life after death and life before life (EDELSTEIN, 1949, p 473). Myth completes the argument about the immortality of the soul. In this Edelstein will make us a question a relevant both "is not ethical myth even more superfluous than cosmological and historical since ethical knowledge is self-sufficient" (EDELSTEIN, 1949, p 473). Plato seems to see that rewards in this or other life do not influence right actions; one must persuade oneself to moral law regardless of its consequences. With this, he intends that righteous not only receive all rewards that virtue brings from man to man, but also those granted by the gods. If the philosopher believes that gods are not indifferent to the destiny of man, he will find a valiant undertaking to be full of good joys and will gain courage. He will exert all his strength in acquiring virtue and wisdom in life (EDELSTEIN, 1949, p.474). The ethical myth speaks of passions of man; it is directed to the irrational part of man in order to persuade it. For both the rational and irrational must be cared for by the philosopher, since pleasure and fear can influence intellect and therefore must be directed (EDELSTEIN, 1949, 474) ${ }^{9}$. Gods are free from passions, unlike men. This is one of the reasons why men need myths and gods do not.

Edelstein will then present the reason for order myths in Plato. The scientific and historical myths appear in the last writings of Plato since work of Forms was already better developed. Timaeus and Critias with their myths intend to give an answer to the problem of creation of the world of phenomena, of nature and of history, explaining Form of Good as cause of all existence (Edelstein, 1949, 475). Ethical myths arise in Gorgias, Phaedo, Phaedrus and the Republic. In Gorgias, Plato recognizes that in human soul there are powers capable of impending decisions of reason. In Phaedo, he speaks of the conflict of the soul with his passions.

8 Cf. Phaedo, 60b.

9 Brisson $(2003,26)$ seems to agree with such a position by saying that "Plato presents this emotional fusion as effect of an enchantment, which plays in the soul the role of remedy, of a fascination or simply of persuasion, aroused by pleasure which the communication of myth provides to lower part of soul (epithymia)". 
In Phaedrus and in Republic, he develops the dogma of tripartition of soul and demonstrates that reason must govern and passions must be governed. Myth in Protagoras, for Edelstein, despite having Plato's brushstrokes, is a historical reproduction of Protagoras's thoughts (Edelstein, 1949, pp. 475-476).

For Edelstein, myth is formed according to reason, this causes the irrational part to agree with the rational part. In this way, using myth does not represent an anti-rational, but a necessary form of expression of intellect. Edelstein's central thesis is that the function of myth in Plato is a dialectical structure (Edelstein, 1949, p477), but admits that a greater detail of his thesis is needed. The classification presented by Edelstein seems to us good, but still insufficient, since it excludes myths that appear in dialogues, but cannot be placed in either of two classifications. For this, we see two alternatives. The first would be to say that such myths are not myths. But this seems to complicate and not solve the issue, omitting a more careful investigation into them. The second alternative that, at first, we agree, is to classify them as a third group. This group would include the non-philosophical myths, those that are in mouths of poets and of many (polloi). Such myths should not enter just polis. As an example, we can cite myth of Ring of Gyges (Rep., 359b-360b), which, being in the mouth of Glaucon and outside classifications given by Edelstein, would be a non-philosophical myth and therefore would be outside just polis.

In this respect, Edelstein does not fail to admit that his analysis of Platonic myths was not sufficiently detailed and presents a methodology to be followed, from his studies to those who take an interest in the subject (Edelstein, 1949, p.447). Even so, rehearse a response minimally. For him, one must analyze Plato's attitude of how mythology affects his judgment on poetry. Plato recognizes that it is the poet's task to compose myths, not being the task of those who are founding the city ${ }^{10}$. However, we are left with the question: who is the poet of the Republic? Being the philosophy different from poetry, cannot be a philosopher also poet. The founders of cities establish myth models to be composed by poets, not those who make myths but these. But Plato composes myths. So, is Plato a poet and a philosopher too? Is philosophy definitely separated from poetry? It seems that in this case, the answer is no. For Edelstein, Plato writes myths for the realization of the philosopher, which should be used in the education of the guardian of just polis. Their philosophical myths should not be limited only to the education of the young, but to go beyond and educate citizen in general. It does not seem to us, however, that Plato is writing his dialogues for mass, so why would he want to persuade himself through myth? Edelstein says it is not Plato's intention to be read by children in school, but his myths are told. If we think of a global political sphere, perhaps we could accept such an argument, after all, the myths were mostly sung by poets or reproduced by rhapsodies. But if we take into account that Plato chose to write myths in his dialogues, not only reporting them and that at the time when he wrote only Greek elite could read, it does not seem to him that he could be writing for mass, which makes such an argument seem odd. For us, a myth written by Plato in his dialogues did not aim at the masses as its main receiver, but rather those who are able to read it. Perhaps, in an alternative to Edelstein's suggestion, we may think that Plato was concerned to educate his readers to philosophy, and once they were persuaded of its benefits, (re) produced their myths to the masses in an attempt to persuade them good.

In Book II of Republic, in determining the terms of education, Socrates will come to the conclusion that the best paideia is gymnastics for the body and music for the soul (Rep., 376e). Beginning with music, we

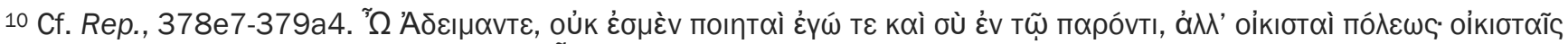

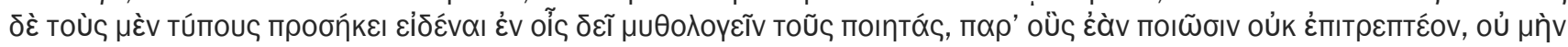

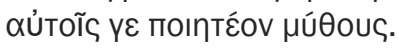


will find that there are two kinds of logos: one true and one false. Both will be taught, but first logos. These are nothing more than myths that will be taught to children (Rep., 377a). The counted myths are thus the first education that children receive, and will be defined by Socrates in the following way:

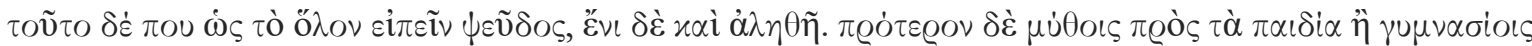
$\chi \varrho \dot{\omega} \mu \varepsilon \theta \alpha$.

in the whole, these are false, although they contain some truth. And we use myths for children before we send them to gyms. (Rep., 377a)

We understand here that myth is not enunciation of false properly because falsehood itself and truth are part of its structure and in itself are confused. In this, the myth has its own significant world, where such classifications are not found, and it seems to be part of a third kind of logos, being neither true nor false. That is, in its function, myth is not opposed to logos. That said, Socrates will continue:

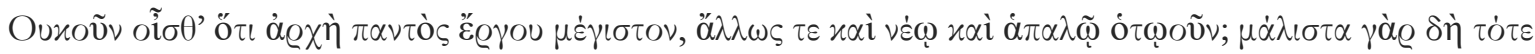

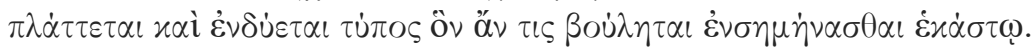

Now, do you know that in any enterprise, the most laborious is the beginning, especially for those who are young and tender? For it is in this phase that one is molded, and buries the matrix that someone wants to print on a person. (Rep., 377a-b)

We can see that greatest argon is principle [å $\chi \dot{\eta}]$, which is linked to myths that are told to younger,

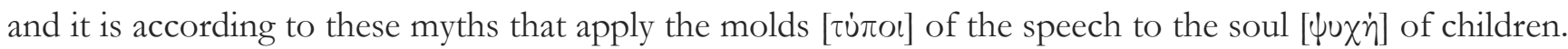

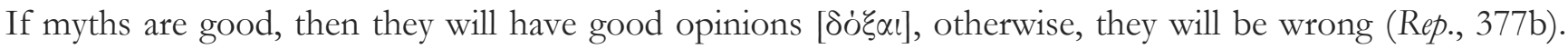
Therefore, one should guard against authors of myths [ $\left.\mu \nu \theta o \pi \circ o^{i}\right]$ and select beautiful myths, refusing bad ones (Rep., 377b-c).

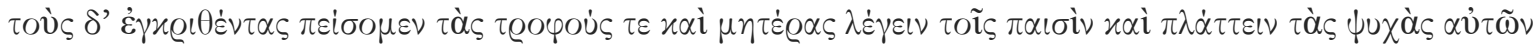

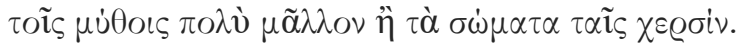

Those who are chosen will persuade mothers and mothers to tell them to children, and to shape their souls through myths, much more carefully than bodies with their hands. (Rep., 377c)

Who is new is still deprived of reasoning [ä $\varrho \omega \nu]$ (Rep. , 378a) is not able to distinguish what is

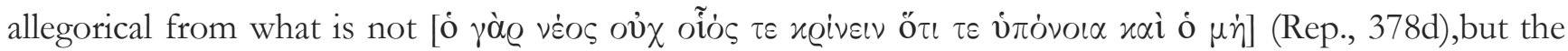

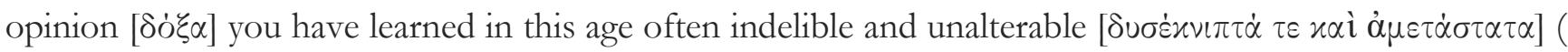
Rep. , 378e ). Therefore, the earliest myths they hear should be composed as beautifully as possible, oriented

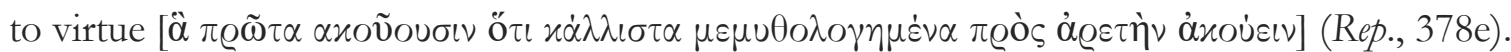

In fact, Plato believed that myth contained truth, which, by its definition in the Republic, makes myth an ambiguous structure: it is neither false nor true. It does not seem to us, therefore, that what distinguishes philosophical myth from other myths is the truth contained in it, but its beauty [ $\left.\varkappa_{\alpha} \lambda_{\mathrm{o}}\right]$ and its

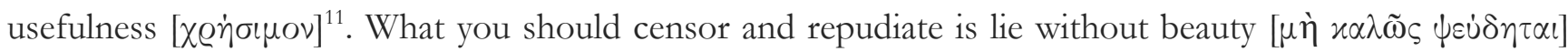

11 To understand the argument of beauty to impart the passage of Rep., 377c-378e; for the utility argument see Rep., 382c-d. 
(Rep., 377d), this being the true lie [ $\dot{\alpha} \lambda \eta \theta \tilde{\omega} \varsigma \psi \varepsilon \tilde{v} \delta o \varsigma]$, hated by all gods and men (Rep., 382a). Finally, let us

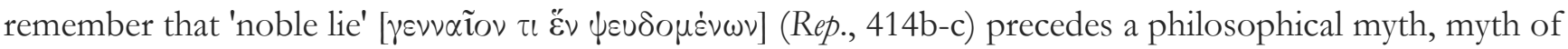
metals, and even so it ceases to be false. In the Republic, the truth contained in myth must be analyzed in order of its utility for just polis.

With the advent of writing, the myths began to be recorded, which helped to consecrate them as part of Greek literature. Brisson argues that myths are formed from the events that collectivity strives to keep in mind (BRISSON, 1982, p.23). Therefore, there is a collective effort to remember, for, in an oral civilization, memory is undissociated from oblivion, because what is not saved by memory is discarded and forgotten (Brisson 1982: 25). This is an important point to emphasize: connection of myth with memory. In Plato, although we cannot classify myths for a single cause (FRUTIGER, 1976, p.2), we can say that they also have the same relation to memory. To understand Gyges' narrative in the Republic, for example, we need to understand the relation of Gyges to Gyges' tradition. His deeds are remembered by lyrical and by history, and have been recorded by writing; has a popular recurrence, which reinforces its memory among many (pollor). However, the tradition of Gyges is near temporally of time in which he lived, not having with lyrical a mythical relation for not being in an unknown past. Another factor is its historicity, since being a historical figure, could hardly be considered a mythical figure. For Kirk, there is a distinction between what can be considered myth and what can be a legend; historical or quasi-historical figures are not considered myths, but they are in the class of popular legends (KIRK, 1990, pp. 23-4), so Gyges could not be considered a myth, according to tradition. However, a tradition that consecrated Gyges for his riches and his great deeds was recorded, and undeniably, was very much told among chicken. This made Plato take ownership of this popular tradition, to compose his myth of Gyges' ring, which marks an important element of argument he is developing.

According to Morgan, "the philosophical myth is rational, implanted as a result of methodological reflection and is a manifestation of philosophical concerns" (MORGAN, 2004, p.7). In Plato, myth usually appears when one does not know the truth about the distant past (Rep., 382d); and, many times, to talk about questions of the soul. By presenting different functions, Plato's myths cannot be classified into a single theory. Edelstein's position seems strange when he says that there is no real dispute between philosophy and poetry, as long as it passes through censorship of truth (Edelstein, 1949: 479). Or to say that "truth is the supreme deity" (Edelstein, 1949, 480). Such statements do not seem to fit the text of Plato, for it is not the truth, in our view, the paradigm that constitutes myths of Plato. Plato with his dialogues gave to the philosophy a new mythology and, consequently, a new poetry. However, for us, this new poetry is not based on the truth, since, according to Edelstein, Plato "was the last one to believe in truth contained in the myth" (Edelstein, 1949, 481).

In conclusion, we can say that Platonic myths are philosophical resources for Plato can better develop his answers. For Edelstein, Platonic myths cannot be unified into a single theory. The author, however, presents an interesting way of interpreting interior of Plato's philosophical work. There are other linguistic devices, beyond dialectics, to be able to explain something. In this way we can understand that there is an introductory moment to myth that is not the same as dialectics, both being acceptable in Plato's philosophy, myth as being the analogy of truth achieved only by dialectics. And we have many aspects of myth in Plato that can be left in a different way of interpretation, but myth is a symbolic explanation of pure reason of dialectics. Dialectics is central to Plato's theory of knowledge. It is through dialectics that computer is in the direction of maximum knowledge. Myth, therefore, does not function as a substitute for dialectics, but as a didactic complement to the teaching of philosophy. 
Our work does not pretend to account for the whole possible relation of the myth in Plato, but only a brief overview of function of myth in his philosophy. The image has capacity to serve as a fantastic didactic instrument and Plato was aware of it. That is why his philosophical myth is intended to serve as another resource for teaching, as if it were an introductory apprenticeship to the path of philosophy.

\section{Bibliography:}

\section{Editions and translations of Republic}

BLOOM, A. (1991). The Republic of Plato. Tradução de Allan Bloom. New York: Basic Books. BURNET, J. (1902). Platonis Opera, recognovit brevique adnotatione critica instrvxit: loannes Burnet, Tomvs IV. Oxford: Oxford University Press.

\section{Studies}

BRISSON, L. (2003). Religion as the Grounding of Philosophical Reflection and as a means of Political Action in Plato's Laws. Translation by Cláudio William Veloso. Kriterion, n. 107, p. 24-38.

BRISSON, L. (1982). Platon les Mots et les Mythes. Paris: Librarie François Maspero.

EDELSTEIN, Ludwig. (1949). The Function of the Myth in Plato's Philosophy. Journal of the History of Ideas, Pennsylvania, v. 10, n. 4, p. 463-481.

KIRK, G. S. (1990). The Nature of Greek Myths. London: Penguin Books.

MORGAN, K. (2004). Myth and Philosophy. From Presocratics to Plato. Cambridge: Cambridge University Press.

TATE, J. (1929). Plato and Allegorical Interpretation. The Classical Quarterly, Cambridge, v. 23, n. 3/4, p. 142-154.

VEYNE, P. (1987). Did the Greeks believe in their Myths? Translation by António Gonçalves. Lisbon: Edições 70.

Artigo recebido em: 01 de julho de 2019

Artigo aceito em: 19 de julho de 2019 